\title{
Blocking Interleukin-12 and Interleukin-23 in the Treatment of Axial Spondyloarthritis
}

\section{Denis Poddubnyy, MD}

\section{Address}

Rheumatology, Med. Department I, Campus Benjamin Franklin, Charité Universitätsmedizin Berlin, Hindenburgdamm 30, 12203, Berlin, Germany Email: denis.poddubnyy@charite.de

Published online: 2 April 2015

(C) Springer International Publishing AG 2015

This article is part of the Topical Collection on Spondyloarthritis and Psoriatic Arthritis

Keywords Ankylosing spondylitis • Non-radiographic axial spondyloarthritis • Therapy • Interleukin-12 • Interleukin-23 - Th17

\section{Opinion statement}

Currently, there are only two effective drug classes approved for treatment of ankylosing spondylitis (AS)/axial spondyloarthritis (axSpA): non-steroidal anti-inflammatory drugs (NSAIDs) and, if NSAIDs fail, tumour necrosis factor (TNF)- $\alpha$ blockers. Although the majority of patients do respond well to these treatment options, there is certainly an unmet need for further therapeutic options for patients who do not respond to, do not tolerate or have contraindications for NSAIDs and TNF- $\alpha$ blockers. Blockade of the Th17 pathway that includes inhibition of interleukins (IL)-12/23 and to a further extent IL-17 represent currently the most promising therapeutic targets in axSpA. The first positive results on the blockade of IL-12/23 in active AS should be confirmed in larger placebocontrolled studies, ideally including the entire population of axSpA. It is very important to identify whether IL-12/23 and IL-17 blockade also works in TNF- $\alpha$ blocker non-responders and if there are specific predictors of response to one or another drug class. Also, effects of this therapy on long-term outcomes including progression of structural damage in the spine in AS/axSpA are of high importance and should be evaluated.

\section{Introduction}

Axial spondyloarthritis (axSpA) is a chronic inflammatory rheumatic disease characterized by predominant involvement of the spine and/or sacroiliac joints. Two forms or stages of axial SpA are covered by the
Assessment of Spondyloarthritis International Society (ASAS) classification criteria [1]: a non-radiographic form (no definite structural damage on X-rays of sacroiliac joints and spine), also called non-radiographic 
axSpA (nr-axSpA), and a radiographic form (with structural damage on conventional X-rays-radiographic sacroiliitis [2] and/or syndesmophytes in the spine), better known as ankylosing spondylitis (AS) [3].

In contrast to other inflammatory rheumatic diseases, such as rheumatoid arthritis, the therapeutic options in axSpA are limited and include non-steroidal anti-inflammatory drugs (NSAIDs) as the first-line therapy and, if this treatment fails, tumour necrosis factor (TNF)- $\alpha$ blockers. There are some differences in the current approval status for TNF blockers in nr-axSpA and AS. First, in contrast to the EU, none of TNF blockers is approved for nr-axSpA in the USA. Second, not all TNF blockers approved for AS treatment in the EU (adalimumab, certolizumab pegol, etanercept, golimumab, infliximab and infliximab biosimilars) are also approved for nr-axSpA (currently available are adalimumab, certolizumab pegol and etanercept; golimumab will probably receive an approval in 2015, infliximab and its biosimilars will probably not be approved for nr-axSpA at all). And third, in AS, TNFblockers are indicated if high disease activity (as indicated by the Bath Ankylosing Spondylitis Disease Activity
Index-BASDAI value of 4 and higher on a 0 to 10 scale) is present despite NSAIDs therapy (or without NSAIDs if contraindicated/not tolerated). In nr-axSpA, objective signs of inflammation (elevated C-reactive protein$\mathrm{CRP}$ or osteitis on magnetic resonance imaging-MRI) are required in addition to clinical disease activity and failure of NSAIDs for initiation of TNF blocking therapy.

Although NSAIDs and TNF blockers are effective in the majority of axSpA patients, there is still a substantial proportion of patients (20-30\%) who do not respond adequately to the currently available treatment [4-6]. According to the actual version of the joined ASAS/European League Against Rheumatism (EULAR) recommendations, disease-modifying anti-rheumatic drugs (DMARDs) and glucocorticoids play only a limited role in the treatment of AS and to a further extent of axSpA [7]. Furthermore, the majority of other biologics approved for or effective in the treatment of rheumatoid arthritis (targeting $\mathrm{T}$ cells-abatacept, B cells-rituximab, IL-1-anakinra or IL-6-tocilizumab and sarilumab) failed to demonstrate clinical efficacy in AS [8-11]. Thus, there is still an unmet need for new therapeutic options in axSpA.

\section{The role of Th17 axis, IL-12 and IL-23 in axial spondyloarthritis}

Th17 cells is a recently identified $\mathrm{T}$ cell subset deriving from naive $\mathrm{T}$ cells under influence of IL-23 [12]. IL-23 together with TGF- $\beta$ and IL-6 stimulates naive precursors cells to differentiate into a Th17 subset producing proinflammatory cytokines (IL-17A, IL-17F, IL-6 and TNF- $\alpha$ ) [12-14]. Even more important seems to be the role of IL-23 in maintaining the Th17 phenotype and to acquire the full effector function $[15,16]$. Currently available data indicate that Th17 cells play a crucial role in the number of chronic autoimmune diseases including psoriasis, psoriatic arthritis and other spondyloarthritides such as AS/axSpA [17-19].

In AS, an increased number of circulating polyfunctional Th17 cells and an elevated level of serum IL-17 were reported [20-23]. Furthermore, an immunohistological analysis of IL-17 secreting cells in facet joints from AS patients indicates a significantly higher frequency of IL-17-producing cells compared to facet joint samples obtained from patients non-inflammatory spinal disorders [24]. Clinical efficacy of IL-17 blockade with a fully human antibody to IL-17A (secukinumab, formerly AIN457, Novartis) was demonstrated in two phase III trials in psoriasis [25] and in proof-of-concept trials in psoriatic arthritis [26] and AS [27•]. Most recently, positive results of the phase III programme with secukinumab in PsA [28] and AS [29, 30] were presented. It could be expected that secukinumab will be consequently approved for the treatment of psoriasis, psoriatic arthritis and AS in 2015-2016. 
Secukinumab will be probably followed by two further IL-17 inhibitors: ixekizumab (Lilly) [31] — a humanized anti-interleukin-17 monoclonal antibody and brodalumab (Amgen) [32]-human anti-interleukin-17-receptor monoclonal antibody, which are currently at different stages of the clinical study programme in psoriasis, psoriasis arthritis and AS/axial SpA.

There is an increasing evidence that IL-23 plays a central role in several autoimmune diseases including SpA. IL-23 is a heterodimeric cytokine sharing the 40-kDa heavy chain (p40) with IL12. The light chains are different in these two cytokines: p35 in IL-12 and p19 in IL-23 [33]. Despite structural similarity, IL-12 and IL-23 have discrete roles in the regulation of T cell immunity. IL-12 is an important factor for the differentiation of naïve T cells into IFN- $\gamma$-producing Th1 cells. Using IL-12 p40-deficient mice and anti-p40 antibodies, it was demonstrated that $\mathrm{p} 40$ was required for the development of T-cell-mediated autoimmune diseases such as experimental allergic encephalomyelitis (EAE), collagen-induced arthritis (CIA), and inflammatory bowel disease [16]. However, IFN- $\gamma$-deficient mice remained susceptible to these diseases, suggesting that IFN- $\gamma$ is not essential for the modelled autoimmune disorders [16]. Further studies showed that mice deficient in either the p19 subunit (lacking IL-23 alone) or the p40 subunit (lacking both IL-12 and IL-23) were resistant to EAE and CIA, whereas p35-deficient mice (lacking IL-12 only) remained susceptible to these diseases [34]. These data indicated that rather IL-23 and not IL-12 is essential for the development of at least some of the autoimmune disease.

A genome-wide association studies showed that polymorphism in IL-23 receptor is associated with susceptibility to AS [35, 36]. Misfolding of HLAB27 in carriers of this antigen might lead to induction of unfolded protein response in the macrophages with an increased IL-23 production by these cells $[37,38]$ that its turn leads to activation of Th17 cells. It was also demonstrated that IL-23 is able to induce SpA-specific entheseal inflammation in vivo [39]. Finally, in situ analysis of IL-23-positive cells in bone marrow and in fibrous tissue replacing bone marrow in facet joints of AS patients revealed a significantly higher number of IL-23-producing cells in comparison to samples obtained from patients without inflammatory spinal disorder [40], and elevated IL-23 levels were found in peripheral blood and synovial fluid in AS patients $[23,41]$. In the following part, we will discuss the therapeutic potential of IL-12 and especially IL-23 blockade in axSpA.

\section{Blockade of IL-12 and IL-23 in axial spondyloarthritis}

Currently, there is only one approved drug blocking IL-12 and IL-23ustekinumab (STELARA, Centocor/Johnson \& Johnson/Janssen-Cilag). Ustekinumab is a fully human IgG1 $\kappa$ monoclonal antibody binding with high affinity and specificity to the p40 protein subunits of IL-12 and IL-23. This prevents IL-12 and IL-23 from binding to their IL-12R $\beta 1$ receptor protein expressed on the surface of immune cells. Ustekinumab has been shown to be effective in the treatment of psoriasis [42-44] and psoriatic arthritis $[45,46 \bullet, 47]$ that resulted in the approval of ustekinumab in the EU and in the USA for treatment of these two conditions. The approved dose of ustekinumab is $45 \mathrm{mg}$ (90 mg for patients with body weight $>100 \mathrm{~kg}$ ) administered 
subcutaneously at weeks 0 and 4 and every 12 weeks thereafter. There is also a signal that ustekinumab might be effective in Crohn's disease [48]. Less data are available concerning efficacy of ustekinumab in axSpA.

In a phase III trial with ustekinumab in psoriatic arthritis (PSUMMIT 1), 172 of 615 patients had axial involvement (spondylitis). In this subgroup, treatment with ustekinumab resulted in a $\geq 50 \%$ improvement of the BASDAI (BASDAI50 response) at week 24 in $23.5 \%(12 / 51)$ of the patients who received ustekinumab $45 \mathrm{mg}, 31.7 \%(19 / 60)$ of the patients treated with ustekinumab $90 \mathrm{mg}$ as compared to $13.1 \%(8 / 61)$ in the placebo-treated group (statistically significant was only the difference ustekinumab $90 \mathrm{mg}$ vs. placebo, $p=0.014)[46 \bullet]$.

We performed recently a proof-of-concept open-label trial with ustekinumab in patients with active AS (TOPAS) [49•]. In this trial, ustekinumab in a dose of $90 \mathrm{mg}$ was administered subcutaneously at baseline, week 4 and week 16 in 20 patients with active AS. Active disease was defined as a BASDAI score of $\geq 4$ despite NSAIDs treatment. At week 24, Assessment of SpondyloArthritis International Society (ASAS) 40 response (the primary end-point) was reached by $65 \%$ of the patients. ASAS20 response, BASDAI50 response and ASAS partial remission were achieved by 75,55 and $30 \%$ of the patients, respectively. In line with these data, 50 and $20 \%$ of the patients achieved the AS disease activity score (ASDAS) clinically important improvement and major improvement, respectively. At week 24, $35 \%$ of the patients had an ASDAS inactive disease (ASDAS <1.3). Importantly, there was a correlation between clinical response and improvement of objective markers of inflammationserum CRP and osteitis in the axial skeleton on MRI. CRP serum level at week 24 went down as compared to baseline in the ASAS40 responders group $(-1.1 \pm 7.5 \mathrm{mg} / \mathrm{l})$ while there was even a CRP increase in nonresponders $(+3.3 \pm 3.5 \mathrm{mg} / \mathrm{l}), p=0.008$. Similarly, osteitis change score in the sacroiliac joints at week 24 was $-3.1 \pm 3.8$ in ASAS40 responders as compared with $+0.6 \pm 1.3$ in non-responders, $p=0.015$; osteitis change score in the spine after 24 weeks of treatment was $-1.9 \pm 1.9$ in ASAS40 responders as compared with $+1.0 \pm 2.4$ in non-responders, $p=0.023[49 \bullet]$. Thus this small proof-of-concept study provided a signal that ustekinumab (and in general blockade of IL-12/23) might be effective for treatment of active AS/axial SpA. These results should be confirmed in a larger placebo-controlled trial, ideally including the entire spectrum of axSpA: AS and nr-axSpA. A further step would be to demonstrate efficacy of ustekinumab in patients not responding to TNF blockers and to identify specific predictors of response to one or another drug class if any. And finally, an effect of IL-12/23 blockade on structural damage progression in the spine in axSpA should be investigated.

Another anti-p40 monoclonal antibody briakinumab (Abbott/AbbVie) has been successfully studied in psoriasis [50, 51], but further development of the drug was suspended.

There are several anti-p19 antibodies blocking, therefore, IL-23 only, which are at different stages of the clinical development programmes. The BI 655066 compound (Boehringer Ingelheim) - a monoclonal antibody against p19 subunit of IL-23-is being currently investigated in psoriasis (studies with clinicaltrials.gov identifiers NCT02203851 and NCT02054481), Crohn's disease (NCT02031276) and AS (NCT02047110). Guselkumab (Janssen)—also an anti-IL-23 p19 antibody-has entered an extensive study programme in 


\section{Conclusion}

psoriasis [52] and is also under investigation in psoriatic arthritis now (NCT02319759). The third anti-IL 23p19 antibody, which is underway in a clinical trial in psoriasis now, is tildrakizumab (Merck Sharp \& Dohme, study NCT01722331). It could be expected that these drugs will also consequently be tested in other forms of SpAs and SpA-related conditions in the next years.

So far, no new safety issues (as compared to TNF-blockers) has been raised in relation to IL-12/23 inhibition (with data mainly related to ustekinumab $[53,54])$; standard precautions concerning infection risk including tuberculosis should be applied upon initiation of anti-IL-12/23 therapy.

IL-12/23 and IL-17 represent nowadays the most promising future therapeutic targets in axial SpA/AS. It seems that efficacy of IL-12/23 or IL-17 blockade on the entire group level is similar to that in TNF blockers. Therefore, it is extremely important to find out if there are patients responding to one drug class and not responding to another one-trials in patients with AS/axial SpA who failed to respond to anti-TNF therapy and studies with cross-sectional design and head-tohead comparisons of biologics should follow. In addition, long-term data with analysis of the impact of the novel drugs on radiographic spinal progression are of high interest and clinical relevance.

\section{Compliance with Ethics Guidelines}

\section{Conflict of Interest}

Denis Poddubnyy reports grants from Janssen-Cilag, during the conduct of the study; personal fees from AbbVie, MSD, Novartis, Pfizer, and UCB; personal fees from AbbVie, Bristol-Myers Squibb, Janssen-Cilag, MSD, Novartis, Pfizer, Roche, and UCB, outside the submitted work.

\section{Human and Animal Rights and Informed Consent}

This article does not contain any studies with human or animal subjects performed by any of the authors.

\section{References and Recommended Reading}

Papers of the particular interest, published recently, have been highlighted as:

\section{- Of importance}

1. Rudwaleit M, van der Heijde D, Landewe R, Listing J, Akkoc N, Brandt J, et al. The development of Assessment of SpondyloArthritis international Society classification criteria for axial spondyloarthritis (part II): validation and final selection. Ann Rheum Dis. 2009;68(6):777-83.

2. van der Linden S, Valkenburg HA, Cats A. Evaluation of diagnostic criteria for ankylosing spondylitis. A proposal for modification of the New York criteria. Arthritis Rheum. 1984;27(4):361-8.

3. Rudwaleit M, Khan MA, Sieper J. The challenge of diagnosis and classification in early ankylosing spondylitis: do we need new criteria? Arthritis Rheum. 2005;52(4):1000-8.

4. Braun J, Deodhar A, Dijkmans B, Geusens P, Sieper J, Williamson $P$, et al. Efficacy and safety of infliximab in patients with ankylosing spondylitis over a two-year period. Arthritis Rheum. 2008;59(9):1270-8.

5. Davis Jr JC, van der Heijde DM, Braun J, Dougados M, Clegg DO, Kivitz AJ, et al. Efficacy and safety of up to 192 weeks of etanercept therapy in patients with ankylosing spondylitis. Ann Rheum Dis. 2008;67(3):346-52. 
6. van der Heijde D, Schiff MH, Sieper J, Kivitz A, Wong RL, Kupper H, et al. Adalimumab effectiveness for the treatment of ankylosing spondylitis is maintained for up to 2 years: long-term results from the ATLAS trial. Ann Rheum Dis. 2009;68(6):922-29.

7. Braun J, van den Berg R, Baraliakos X, Boehm H, Burgos-Vargas R, Collantes-Estevez E, et al. 2010 update of the ASAS/EULAR recommendations for the management of ankylosing spondylitis. Ann Rheum Dis. 2011;70(6):896-904.

8. Song IH, Heldmann F, Rudwaleit M, Haibel H, Weiss A, Braun J, et al. Treatment of active ankylosing spondylitis with abatacept: an open-label, 24-week pilot study. Ann Rheum Dis. 2011;70(6):1108-10.

9. Song IH, Heldmann F, Rudwaleit M, Listing J, Appel H, Braun J, et al. Different response to rituximab in tumor necrosis factor blocker-naive patients with active ankylosing spondylitis and in patients in whom tumor necrosis factor blockers have failed: a twenty-four-week clinical trial. Arthritis Rheum. 2010;62(5):1290-7.

10. Sieper J, Porter-Brown B, Thompson L, Harari O, Dougados M. Assessment of short-term symptomatic efficacy of tocilizumab in ankylosing spondylitis: results of randomised, placebo-controlled trials. Ann Rheum Dis. 2014;73(1):95-100.

11. Sieper J, Braun J, Kay J, Badalamenti S, Radin AR, Jiao L, et al. Sarilumab for the treatment of ankylosing spondylitis: results of a Phase II, randomised, double-blind, placebo-controlled study (ALIGN). Ann Rheum Dis. 2014. doi:10.1136/annrheumdis-2013-204963.

12. Bettelli E, Korn T, Oukka M, Kuchroo VK. Induction and effector functions of T(H)17 cells. Nature. 2008;453(7198):1051-7.

13. Harrington LE, Hatton RD, Mangan PR, Turner H, Murphy TL, Murphy KM, et al. Interleukin 17producing CD4+ effector T cells develop via a lineage distinct from the T helper type 1 and 2 lineages. Nat Immunol. 2005;6(11):1123-32.

14. Acosta-Rodriguez EV, Napolitani G, Lanzavecchia A, Sallusto F. Interleukins 1 beta and 6 but not transforming growth factor-beta are essential for the differentiation of interleukin 17-producing human T helper cells. Nat Immunol. 2007;8(9):942-9.

15. Stritesky GL, Yeh N, Kaplan MH. IL-23 promotes maintenance but not commitment to the Th17 lineage. J Immunol. 2008;181(9):5948-55.

16. Matsui M. Roles of the novel interleukin-12-associated cytokine, interleukin-23, in the regulation of T-cellmediated immunity. Hepatol Res. 2007;37 Suppl 3:S310-8.

17. Shen H, Goodall JC, Hill Gaston JS. Frequency and phenotype of peripheral blood Th17 cells in ankylosing spondylitis and rheumatoid arthritis. Arthritis Rheum. 2009;60(6):1647-56.

18. Leipe J, Grunke M, Dechant C, Reindl C, Kerzendorf U, Schulze-Koops H, et al. Role of Th17 cells in human autoimmune arthritis. Arthritis Rheum.

2010;62(10):2876-85.
19. Kagami S, Rizzo HL, Lee JJ, Koguchi Y, Blauvelt A. Circulating Th17, Th22, and Th1 cells are increased in psoriasis. J Invest Dermatol. 2010;130(5):1373-83.

20. Wendling D, Cedoz JP, Racadot E, Dumoulin G. Serum IL-17, BMP-7, and bone turnover markers in patients with ankylosing spondylitis. Joint Bone Spine. 2007;74(3):304-5.

21. Jandus C, Bioley G, Rivals JP, Dudler J, Speiser D, Romero P. Increased numbers of circulating polyfunctional Th17 memory cells in patients with seronegative spondylarthritides. Arthritis Rheum. 2008;58(8):2307-17.

22. Wang X, Lin Z, Wei Q, Jiang Y, Gu J. Expression of IL-23 and IL-17 and effect of IL-23 on IL-17 production in ankylosing spondylitis. Rheumatol Int. 2009;29(11):1343-7.

23. Mei Y, Pan F, Gao J, Ge R, Duan Z, Zeng Z, et al. Increased serum IL-17 and IL-23 in the patient with ankylosing spondylitis. Clin Rheumatol. 2011;30(2):269-73.

24. Appel H, Maier R, Wu P, Scheer R, Hempfing A, Kayser $\mathrm{R}$, et al. Analysis of IL-17(+) cells in facet joints of patients with spondyloarthritis suggests that the innate immune pathway might be of greater relevance than the Th17-mediated adaptive immune response. Arthritis Res Ther. 2011;13(3):R95.

25. Langley RG, Elewski BE, Lebwohl M, Reich K, Griffiths CE, Papp K, et al. Secukinumab in plaque psoriasisresults of two phase 3 trials. N Engl J Med. 2014;371(4):326-38.

26. McInnes IB, Sieper J, Braun J, Emery P, van der Heijde D, Isaacs JD, et al. Efficacy and safety of secukinumab, a fully human anti-interleukin-17A monoclonal antibody, in patients with moderate-to-severe psoriatic arthritis: a 24-week, randomised, double-blind, placebocontrolled, phase II proof-of-concept trial. Ann Rheum Dis. 2014;73(2):349-56.

27. Baeten D, Baraliakos X, Braun J, Sieper J, Emery P, van der Heijde D, et al. Anti-interleukin-17A monoclonal antibody secukinumab in treatment of ankylosing spondylitis: a randomised, double-blind, placebocontrolled trial. Lancet. 2013;382(9906):1705-13.

A proof-of-concept study, which demonstrated for the first time clinical efficacy of IL 17 blockade with secukinumab in ankylosing spondylitis.

28. Mease P, McInnes I, Kirkham B, Kavanaugh A, Rahman $\mathrm{P}$, van der Heijde D, et al. Secukinumab, a human antiinterleukin-17A monoclonal antibody, improves active psoriatic arthritis and inhibits radiographic progression: efficacy and safety data from a phase 3 randomized, multicenter, double-blind, placebo-controlled study. Arthritis Rheum. 2014;66(11(Suppl)):S423.

29. Baeten D, Braun J, Baraliakos X, Sieper J, Dougados M, Emery $P$, et al. Secukinumab, a monoclonal antibody to interleukin-17A, significantly improves signs and symptoms of active ankylosing spondylitis: results of a 52-week phase 3 randomized placebo-controlled trial with intravenous loading and subcutaneous 
maintenance dosing. Arthritis Rheum. 2014;66(11(Suppl)):S360.

30. Sieper J, Braun J, Baraliakos X, Baeten D, Dougados M, Emery $\mathrm{P}$, et al. Secukinumab, a monoclonal antibody to interleukin-17A, significantly improves signs and symptoms of active ankylosing spondylitis: results of a phase 3, randomized, placebo-controlled trial with subcutaneous loading and maintenance dosing. Arthritis Rheum. 2014;66(11(Suppl)):S232.

31. Leonardi C, Matheson R, Zachariae C, Cameron G, Li L, Edson-Heredia E, et al. Anti-interleukin-17 monoclonal antibody ixekizumab in chronic plaque psoriasis. $\mathrm{N}$ Engl J Med. 2012;366(13):1190-9.

32. Papp KA, Leonardi C, Menter A, Ortonne JP, Krueger JG, Kricorian G, et al. Brodalumab, an anti-interleukin17 -receptor antibody for psoriasis. N Engl J Med. 2012;366(13):1181-9.

33. Parham C, Chirica M, Timans J, Vaisberg E, Travis $M$, Cheung J, et al. A receptor for the heterodimeric cytokine IL-23 is composed of IL-12Rbeta1 and a novel cytokine receptor subunit, IL-23R. J Immunol. 2002;168(11):5699-708.

34. Murphy CA, Langrish CL, Chen Y, Blumenschein W, McClanahan T, Kastelein RA, et al. Divergent pro- and antiinflammatory roles for IL-23 and IL-12 in joint autoimmune inflammation. J Exp Med. 2003;198(12):1951-7.

35. Burton PR, Clayton DG, Cardon LR, Craddock N, Deloukas P, Duncanson A, et al. Association scan of 14,500 nonsynonymous SNPs in four diseases identifies autoimmunity variants. Nat Genet.

2007;39(11):1329-37.

36. Rahman P, Inman RD, Gladman DD, Reeve JP, Peddle L, Maksymowych WP. Association of interleukin-23 receptor variants with ankylosing spondylitis. Arthritis Rheum. 2008;58(4):1020-5.

37. DeLay ML, Turner MJ, Klenk EI, Smith JA, Sowders DP, Colbert RA. HLA-B27 misfolding and the unfolded protein response augment interleukin-23 production and are associated with Th17 activation in transgenic rats. Arthritis Rheum. 2009;60(9):2633-43.

38. Turner MJ, Sowders DP, DeLay ML, Mohapatra R, Bai S, Smith JA, et al. HLA-B27 misfolding in transgenic rats is associated with activation of the unfolded protein response. J Immunol. 2005;175(4):2438-48.

39. Sherlock JP, Joyce-Shaikh B, Turner SP, Chao CC, Sathe M, Grein J, et al. IL-23 induces spondyloarthropathy by acting on ROR-gammat+CD3+CD4-CD8- entheseal resident T cells. Nat Med. 2012;18(7):1069-76.

40. Appel H, Maier R, Bleil J, Hempfing A, Loddenkemper $\mathrm{C}$, Schlichting $\mathrm{U}$, et al. In situ analysis of interleukin-23and interleukin-12-positive cells in the spine of patients with ankylosing spondylitis. Arthritis Rheum. 2013;65(6):1522-9.

41. Romero-Sanchez C, Jaimes DA, Londono J, De Avila J, Castellanos JE, Bello JM, et al. Association between Th17 cytokine profile and clinical features in patients with spondyloarthritis. Clin Exp Rheumatol. 2011;29(5):828-34.
42. Leonardi CL, Kimball AB, Papp KA, Yeilding N, Guzzo C, Wang Y, et al. Efficacy and safety of ustekinumab, a human interleukin-12/23 monoclonal antibody, in patients with psoriasis: 76-week results from a randomised, double-blind, placebo-controlled trial (PHOENIX 1). Lancet. 2008;371(9625):1665-74.

43. Papp KA, Langley RG, Lebwohl M, Krueger GG, Szapary P, Yeilding N, et al. Efficacy and safety of ustekinumab, a human interleukin-12/23 monoclonal antibody, in patients with psoriasis: 52-week results from a randomised, double-blind, placebo-controlled trial (PHOENIX 2). Lancet. 2008;371(9625):1675-84.

44. Griffiths CE, Strober BE, van de Kerkhof P, Ho V, Fidelus-Gort R, Yeilding N, et al. Comparison of ustekinumab and etanercept for moderate-to-severe psoriasis. N Engl J Med. 2010;362(2):118-28.

45. Gottlieb A, Menter A, Mendelsohn A, Shen YK, Li S, Guzzo C, et al. Ustekinumab, a human interleukin 12/ 23 monoclonal antibody, for psoriatic arthritis: randomised, double-blind, placebo-controlled, crossover trial. Lancet. 2009;373(9664):633-40.

46. McInnes IB, Kavanaugh A, Gottlieb AB, Puig L, Rahman $\mathrm{P}$, Ritchlin $\mathrm{C}$, et al. Efficacy and safety of ustekinumab in patients with active psoriatic arthritis: 1 year results of the phase 3 , multicentre, double-blind, placebocontrolled PSUMMIT 1 trial. Lancet. 2013;382(9894):780-9.

In this study, efficacy of ustekinumab on axial symptoms was evaluated in a subgroup of psoriatic arthritis patients with spondylitis.

47. Ritchlin C, Rahman P, Kavanaugh A, McInnes IB, Puig L, Li S, et al. Efficacy and safety of the anti-IL-12/23 p40 monoclonal antibody, ustekinumab, in patients with active psoriatic arthritis despite conventional nonbiological and biological anti-tumour necrosis factor therapy: 6-month and 1-year results of the phase 3, multicentre, double-blind, placebo-controlled, randomised PSUMMIT 2 trial. Ann Rheum Dis. 2014;73(6):990-9.

48. Sandborn WJ, Feagan BG, Fedorak RN, Scherl E, Fleisher MR, Katz S, et al. A randomized trial of Ustekinumab, a human interleukin-12/23 monoclonal antibody, in patients with moderate-to-severe Crohn's disease. Gastroenterology. 2008;135(4):1130-41.

49. Poddubnyy D, Hermann KG, Callhoff J, Listing J, Sieper J. Ustekinumab for the treatment of patients with active ankylosing spondylitis: results of a 28-week, prospective, open-label, proof-of-concept study (TOPAS). Ann Rheum Dis. 2014;73(5):817-23.

A proof-of-concept open-label study, which demonstrated for the first time clinical efficacy of IL 12 /23 blockade with ustekinumab in ankylosing spondylitis.

50. Gottlieb AB, Leonardi C, Kerdel F, Mehlis S, Olds M, Williams DA. Efficacy and safety of briakinumab vs. etanercept and placebo in patients with moderate to severe chronic plaque psoriasis. Br J Dermatol. 2011;165(3):652-60.

51. Strober BE, Crowley JJ, Yamauchi PS, Olds M, Williams DA. Efficacy and safety results from a phase III, 
randomized controlled trial comparing the safety and efficacy of briakinumab with etanercept and placebo in patients with moderate to severe chronic plaque psoriasis. Br J Dermatol. 2011;165(3):661-8.

52. Sofen H, Smith S, Matheson RT, Leonardi CL, Calderon C, Brodmerkel C, et al. Guselkumab (an IL-23-specific $\mathrm{mAb}$ ) demonstrates clinical and molecular response in patients with moderate-to-severe psoriasis. J Allergy Clin Immunol. 2014;133(4):1032-40.

53. Langley RG, Lebwohl M, Krueger GG, Szapary PO, Wasfi Y, Chan D, et al. Long-term efficacy and safety of ustekinumab, with and without dosing adjustment, in patients with moderate-to-severe psoriasis: results from the PHOENIX 2 study through 5 years of follow-up. Br J Dermatol. 2014. doi:10.1111/bjd.13469.

54. Papp K, Gottlieb AB, Naldi L, Pariser D, Ho V, Goyal K, et al. Experience with ustekinumab in patients with psoriasis enrolled in a large, multicenter, prospective, disease-based registry (Psoriasis Longitudinal Assessment and Registry [PSOLAR]). J Am Acad Dermatol. 2015. doi:10.1016/j.jaad.2014.10.025. 